\title{
Development of ecological teaching book supplements based on local
} wisdom

\author{
Alif Putra Lestari*, Sri Murtini**, Bambang Sigit Widodo** \\ * Pendidikan Geografi, Program Pascasarjana, Universitas Negeri Surabaya, Jl. Lidah Wetan, \\ Lakarsantri, Surabaya, Jawa Timur, 60213, Indonesia \\ ** Pendidikan Geografi, Fakultas Ilmu Sosial dan Hukum, Universitas Negeri Surabaya, Jl. \\ Lidah Wetan, Lakarsantri, Surabaya, Jawa Timur, 60213, Indonesia
}

\begin{tabular}{l}
\hline ARTICLES INFO \\
\hline Profil Articles: \\
Sent: 21-10-2020 \\
Approved: 6-5-2021 \\
Published: 30-6-2021 \\
\hline
\end{tabular}

\section{Key words:}

Teaching materials; textbook supplements; ecology; local wisdom

\begin{abstract}
Teaching materials are one of the important elements in the learning process that support the achievement of learning objectives, including in ecology courses. Based on the analysis of existing teaching materials, interviews with students and lecturers. There is no material about local wisdom in teaching materials in ecology courses. This study aims to produce an ecological textbook supplement based on local wisdom. The design of this research is research and development (R\&D) with the Dick and Carey model. This research went through the stages of identifying objectives, formulating specific objectives, developing textbook supplements, validation and revision, product testing, and product revision. The results showed that the supplement to the ecological textbooks based on local wisdom was feasible and well accepted by students to be used in the learning process.
\end{abstract}

This is an open access article under the CC-BY-SA license

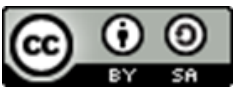

\section{Corresponding Author:}

Alif Putra Lestari

Pendidikan Geografi

Universitas Negeri Surabaya

Jl. Lidah Wetan, Lakarsantri, Surabaya, Jawa Timur 60213

E-mail: alieflestari8@gmail.com

\section{INTRODUCTION}

Educational management requires continuous development, teaching staff, learning methods, learning media, teaching materials, learning resources and so on that support the success of the learning process. According to Rusdiana (2015) a teacher must be able to provide knowledge to students, one of which is through teaching materials. In line with the statement of Amri (2013) that one of the elements that has a major influence on the success of education as a whole is the ability and success of teachers in compiling learning materials. The material contained in the teaching materials needs to be well prepared so that the learning objectives can be achieved. Included in the ecology course, it is necessary to develop teaching materials that can improve students' understanding of the environment.

So far, the ecology course program at Geography Education, State University of Surabaya (UNESA) uses teaching materials that have been provided by the instructor. Based on the results of interviews with several students who have taken ecology courses, it was concluded that the current teaching materials are handouts and contain old material, it is necessary to update the material. Local wisdom is considered attractive to be included in ecology teaching materials. Because there is a lot of local wisdom that has 
Jurnal Pendidikan Geografi:

Kajian, Teori, dan Praktik dalam Bidang Pendidikan dan Ilmu Geografi

Volume 26, Nomor 2, Juni 2021, Hal 85-91

a big influence on the environment. As stated by Pornpimon et al. (2014) that local wisdom needs to be included in learning because it is very useful for students.

Environmental conditions that continue to change need to be included in teaching materials. There are many environmental issues today, apart from a lot of destruction there are also many efforts to protect the natural environment through culture in regions in Indonesia Sufia et al., (2016). This is interesting and important, because students need to get it to strengthen their scientific knowledge, especially in the field of ecology. As the results of the study of Putri et al. (2018) show that students as the younger generation need to be introduced to local community wisdom in utilizing marine resources through teaching material supplements that contain wisdom in the use of marine resources.

Meanwhile, the ecology program at Unesa has never included local wisdom as teaching material. Students want material about local wisdom that is considered important, as well as contextual. In addition, from the results of the questionnaire filled out by students, $75 \%$ of respondents stated that they wanted additional material, namely local wisdom. According to Moreno et al., (2011) education needs to include local wisdom that instills moral concern for the environment because it will help solve ecological problems.

So it is appropriate for the ecology course to make additional material about local wisdom. Because in the ecology syllabus, there is also material for studying the role of local wisdom in environmental sustainability. Local wisdom is a tradition, myth, value or the like that has a positive impact on the preservation of the surrounding environment. This is confirmed by the results of interviews with ecology lecturers. Currently, materials about local wisdom are needed in ecology courses. So far, the material presented is only about pollution of water, soil, air resources and how to handle it and manage the environment. However, it is still general, there has never been any material on environmental management based on local wisdom. Moreover, the contextual one, so far the lecturer has never given such a thing.

The lecturer's statement further emphasized the importance of additional material in the ecology course on local wisdom. The aim of this research is to produce appropriate ecology textbook supplements based on local wisdom. Textbook supplements are additional textbooks that are useful for strengthening and complementing the main teaching materials (Reski et al., 2016).

\section{METHOD}

This study uses a research development design or what is commonly called Research and Development (R\&D). This development research will ultimately produce a product that is suitable for use. This research refers to the Dick and Carey model that is tailored to the needs of the researcher as the basis for developing textbook supplements as the final product. The textbook supplement development model in this study is a set of procedures designed in such a way and carried out coherently according to the sequence of procedures in developing textbook supplements.

Table 1. Interpretation of the textbook supplement eligibility score

\begin{tabular}{cc}
\hline Score & Category \\
\hline $81 \%-100 \%$ & Very Worthy \\
$61 \%-80 \%$ & Worthy \\
$41 \%-60 \%$ & Worthy Enough \\
$21 \%-40 \%$ & Less Worthy \\
$0 \%-20 \%$ & Not Worthy \\
\hline
\end{tabular}

Source: Budiaji (2013) 
Jurnal Pendidikan Geografi:

Kajian, Teori, dan Praktik dalam Bidang Pendidikan dan Ilmu Geografi

Volume 26, Nomor 2, Juni 2021, Hal 85-91

Table 2. Interpretation of student response scores

\begin{tabular}{cc}
\hline Skor & Kategori \\
\hline $0 \%-20 \%$ & Tidak baik \\
$21 \%-40 \%$ & Kurang baik \\
$41 \%-60 \%$ & Cukup baik \\
$61 \%-80 \%$ & Baik \\
$81 \%-100 \%$ & Sangat baik \\
\hline
\end{tabular}

Source: Budiaji (2013)

This research goes through stages 1) Identifying Learning Objectives, 2) Formulating Specific Objectives, 3) Developing Textbook Supplement, 4) Validation and Revision, 5) Product Testing, and 6) Product Revision. The procedure for its implementation is as follows: (a) The identification of objectives is carried out through a needs analysis by means of interviews with ecology lecturers, students, and ecology syllabus analysis. (b) Formulating specific objectives, namely formulating specific statements of what students can do after they complete the learning process that is designed in such a way. (c) Developing textbook supplements, namely designing and making an initial draft of ecology textbook supplements based on local wisdom according to the selected model. The local wisdom referred to in this case is the myth and tradition in Petirtaan Jolotudo, Mojokerto Regency. (d) Validation and revision, namely validating the appropriateness of textbook supplements carried out by linguists, design experts, and content or material experts. Furthermore, the scores obtained will be interpreted using 5 categories as in the Table 1. Improvements are made based on the notes of deficiencies by the validator. (e) Trial, namely trying out textbook supplements to students to get responses (responses or suggestions) from the questionnaires that were distributed. Then scoring and interpreted using 5 categories as as in the Table 2. (f) Product revision, namely the final revision of the product after being validated and getting responses and suggestions from trials.

\section{RESULT AND DISCUSSION}

\section{Textbook Supplement Eligibility}

The feasibility test of textbook supplements is carried out through validation tests by linguists, design experts, and material experts. The textbook supplement produced is considered valid if the final interpretation of the calculation results is in the descent-very feasible category. After being validated by experts, improvements will be made according to the notes from the validators in order to improve product quality. Furthermore, trials will be carried out to get responses and suggestions from students in order to improve product quality, and will be revised again. The final revision is the final stage of the product, which is considered suitable for use in learning ecology courses. According to Tomlison \& Avila (2012) the ideal teaching materials are teaching materials that can provide information and learning experiences and are developed with good designs and features.

Details that are validated by linguists are ease of understanding, suitability of level of thinking, suitability of emotional level, ambiguity, conformity with EYD, use of terms, and continuity. Details that are validated by design experts are the sequence of presentation, use of images, glossary, bibliography, use of fonts, layout, cover illustrations, and product physics. Meanwhile, the details that were validated by material experts were the suitability of the material with the syllabus, conformity with learning objectives, accuracy, attractiveness of the material, up-to-date, and its usefulness. The 
Jurnal Pendidikan Geografi:

Kajian, Teori, dan Praktik dalam Bidang Pendidikan dan Ilmu Geografi

Volume 26, Nomor 2, Juni 2021, Hal 85-91

results of the validation by the expert team were then converted into numbers, the percentage was obtained as in the Table 3 . Based on the Table 3 , the language aspect in the supplement is in the very feasible category, the design aspect is in the very feasible category, and the material aspect is in the feasible category. Then it is averaged and the results are very feasible, which means that the textbook supplements produced are very suitable for use in the learning process.

The language used is in accordance with the rules of a textbook, and is easy to understand. The good choice of words in the textbook supplement has adjusted the thinking level of students who are more critical. Choice of language that is communicative and can increase the reader's motivation to supplement textbooks, so that students can quickly grasp the concepts expressed in them. The language used is also in accordance with the student's emotional level which accelerates student understanding. In line with the statement of Prawindia et al. (2016) quality teaching materials can help students to achieve competencies according to the curriculum and improve the good character of students.

Based on the design aspect, the textbook supplement is already very good. The images presented are in accordance with the description and the font used is ideal for the reader. While the cover illustration in the textbook supplement is not rigid, the material structure displayed is coherent and does not bore the reader. According to Selfiardy (2017) the picture in the right textbook supplement will be able to increase students' understanding. A layout that is not monotonous becomes an added value that makes readers more interested in reading. Teaching materials must be interesting and innovative to increase students' interest in learning (Akbar \& Hartono, 2017). Likewise, the paper used is paper that is suitable, not easily damaged and not blurry.

Based on the content aspect, the textbook supplement is quite good and in accordance with the title, namely the supplementary ecological textbook based on local wisdom. Explaining local wisdom in the form of myths and traditions in Jolotundo, Mojokerto in relation to ecology. The material is interesting for students, because it contains contextual material but most of them have never got it. In accordance with the statement of Tanjung \& Fahmi (2015) that there is a need for efforts from educators to develop teaching materials to suit their needs and raise wisdom in the area where students live. The material presented is in accordance with the study material contained in the RPS of ecology, the material presented is also in accordance with the learning objectives or learning indicators, it only needs theory strengthening.

The description or explanation of the material as well as the supporting pictures presented is coherent and structured, not causing confusion for the reader. The material presented in textbook supplements can provide benefits to broaden readers 'or students' insights. As previously explained, the theme in this textbook supplement is contextual, around students but in general they have never received the material.

Tabel 3. Recapitulation of the results of validation of the eligibility of textbook supplements

\begin{tabular}{llccc}
\hline \multirow{2}{*}{ No } & \multirow{2}{*}{ Eligibilty Aspect } & \multicolumn{3}{c}{ Validator Assessment } \\
\cline { 2 - 4 } & Eligibility of language & Total Score & Percentage & Category \\
\hline 1. & Eligibility of design & 32 & $87,5 \%$ & Very worthy \\
2. & 20 & $89 \%$ & Very worthy \\
3. & Eligibility of content & & $71,4 \%$ & Worthy \\
\hline & Total & & $247,9 \%$ & Very worthy \\
\hline
\end{tabular}


Jurnal Pendidikan Geografi:

Kajian, Teori, dan Praktik dalam Bidang Pendidikan dan Ilmu Geografi

Volume 26, Nomor 2, Juni 2021, Hal 85-91

Utami et al. (2019) also revealed that good teaching materials will provide information that allows students to make intelligent judgments in their daily lives. In general, textbook supplements can be used for learning with some improvements based on the notes of the validators.

\section{Student response to textbook supplements}

Student responses are student responses and suggestions to textbook supplements that have been used by them in learning (trial). Based on the results of the questionnaire recapitulation that has been filled in and processed in such a way, the average score of the response questionnaire was obtained by 36 students, namely $83.45 \%$. In accordance with the student response score interpretation table, the score of $83.45 \%$ is included in the "very good" category in the range of $81 \%-100 \%$. So it can be concluded that ecology textbook supplements based on local wisdom that have been developed can be accepted by students as teaching materials in the learning process. Textbook supplements must have good quality as teaching materials in the learning process (Kurniasari et al., 2014).

According to them, the title used already represents the contents of the textbook supplement, which can provide an overview of the content of the material quickly. The material presented is in accordance with their current needs and is very important to add insight. The material is also very clear and easy for students to understand so that it can increase their motivation in learning ecology courses. Moreover, the material presented is a theme that is around students or is contextual in nature. Teaching materials as a learning component should be arranged based on the environment where the participants live so that it is easier to create, understand, and correlate knowledge (Haryadi et al., 2017). The material presented in this textbook supplement can add new insights and can help increase the breadth of ecology learning materials.

Students also revealed that the textbook supplements that have been developed can help them in the learning process because they use language that is communicative, clear, and easy to understand. Teaching materials that are easy to understand will help the learning process of students (Winarti et al., 2016). In terms of display used, textbook supplements have used fonts that are easy to read, as well as the pictures displayed in accordance with the learning material and help in understanding the existing descriptions. Textbook supplements use a lot of foreign or local terms, but this has been helped by a complete glossary at the end of the book.

Meanwhile, seen from the layout used, the textbook supplement is quite interesting and increases the reader's desire. In general, from the results of the questionnaire summarized by the researchers, ecology textbook supplements based on local wisdom are very good and can be used, according to student assessments. They also provide some written suggestions for products being developed including; The cover design was made even more attractive, the contents of the glossary were increased, and the pictures about Petirtaan Jolotundo were added. The suggestions collected are then used as references for further improvement so that they become quality textbook supplements that can be used as teaching materials in ecology courses. Ecology teaching materials need to be developed, and it is necessary to include ecological facts and phenomena that occur at the local level (Hariyadi et al., 2014).

\section{CONCLUSION}

Based on the results of the research and discussion above, it is concluded that ecology textbook supplements based on local wisdom that have been developed are very suitable for use in ecology courses. Based on the results of the validation of linguists, 
Jurnal Pendidikan Geografi:

Kajian, Teori, dan Praktik dalam Bidang Pendidikan dan Ilmu Geografi

Volume 26, Nomor 2, Juni 2021, Hal 85-91

design experts, and material experts, the resulting product is very suitable for use in the learning process. Students can well receive ecology textbook supplements based on local wisdom to be used in their learning process. Textbook supplements that have been developed need to be applied in the field on an ongoing basis to help achieve learning objectives, and product improvements if needed to make them more perfect as textbooks.

\section{REFERENCES}

Akbar, F. I., \& Hartono, R. (2017). Pengembangan lembar kegiatan peserta didik dengan model pengembangan 4-D pada materi mitigasi bencana dan adaptasi bencana kelas X SMA. Jurnal Pendidikan Geografi: Kajian, Teori, dan Praktek dalam Bidang Pendidikan dan Ilmu Geografi, 22(2), 135-147. https://doi.org/10.17977/ um017v22i22017p135

Amri, S. (2013). Pengembangan dan model pembelajaran dalam kurikulum 2013. PT Prestasi Pustakarya.

Budiaji, W. (2013). Skala pengukuran dan jumlah respon skala likert (the measurement scale and the number of responses in likert scale). Ilmu Pertanian dan Perikanan, 2 (2), 127-133. http://umbidharma.org/jipp

Hariyadi, B., Hamida, A., Kartika, W. D., Yuliastuti, S. L., Ningsih, D., \& Rahma, N. (2014). Perlukah buku ajar Ekologi? Jurnal Biologi Edukasi, 13(6), 64-70.

Haryadi, S., Djatmika, E. T., \& Setyosari, P. (2017). Suplemen buku ajar tematik materi energi alternatif \& sumber daya alam berbasis kontekstual untuk kelas IV SD. Jurnal Pendidikan: Teori, Penelitian, Dan Pengembangan, Volume: 2, 1330-1337.

Kurniasari, D. A. D., Rusilowati, A., \& Subekti, N. (2014). Pengembangan buku suplemen IPA terpadu dengan tema pendengaran kelas VIII. USEJ - Unnes Science Education Journal, 3(2), 462-467. https://doi.org/10.15294/usej.v3i2.3329

Moreno, C. H. P., Acero, I. D. M., \& Rodriguez, N. H. P. (2011). Education for environment care: Contribution through human ecology. Procedia - Social and Behavioral Sciences, 15, 3912-3915. https://doi.org/10.1016/j.sbspro.2011.04.393

Pornpimon, C., Wallapha, A., \& Prayuth, C. (2014). Strategy challenges the local wisdom applications sustainability in schools. Procedia - Social and Behavioral Sciences, 112(Iceepsy 2013), 626-634. https://doi.org/10.1016/j.sbspro.2014.01.1210

Prawindia, L., Fatchan, A., \& Astina, I. K. (2016). Pengembangan bahan ajar Geografi struktur buku Cambridge Fundamentals of Geography untuk kelas XI SMA/MA materi sebaran barang tambang. Jurnal Pendidikan Geografi, 21(1), 53-62. https:// doi.org/10.17977/um017v21i12016p053

Putri, I. H. N., Sholihah, U., Handayani, E. M., \& Sumarmi, S. (2018). Pengembangan suplemen bahan ajar digital pada mata pelajaran Geografi dengan topik bahasan sumber daya laut berbasis kearifan lokal. In Jurnal Pendidikan Geografi: Kajian, Teori, dan Praktek dalam Bidang Pendidikan dan Ilmu Geografi (Vol. 23, Issue 2). https://doi.org/10.17977/um017v23i22018p078

Reski, R., Hairida, H., \& Masriani, M. (2016). Pengembangan suplemen buku ajar berbasis kearifan lokal pada materi biosintesis eikosanoid. Neliti.Com, 1-13. https:// www.neliti.com/publications/191800/pengembangan-suplemen-buku-ajar-berbasiskearifan-lokal-pada-materi-biosintesis

Rusdiana, A. (2015). Pengelolaan pendidikan.pdf (B. A. Saebani (ed.); I). CV Pustaka Setia.

Selfiardy, S. (2017). Pengembangan buku suplemen mata pelajaran Geografi untuk kelas X SMA Muhammadiyah 1 Ponorogo. In Universitas Sebelas Maret Surakarta (Vol. 4). Universitas Sebelas Maret Surakarta. 
Jurnal Pendidikan Geografi:

Kajian, Teori, dan Praktik dalam Bidang Pendidikan dan Ilmu Geografi

Volume 26, Nomor 2, Juni 2021, Hal 85-91

Sufia, R., Sumarmi, S., \& Amirudin, A. (2016). Kearifan lokal dalam melestarikan lingkungan hidup (studi kasus masyarakat adat Desa Kemiren Kecamatan Glagah Kabupaten Banyuwangi). Jurnal Pendidikan: Teori, Penelitian, dan Pengembangan, 1(4), 726-731.

Tanjung, A., \& Fahmi, M. (2015). Urgensi pengembangan bahan ajar Geografi berbasis kearifan lokal. Jurnal Pendidikan Geografi: Kajian, Teori, dan Praktek dalam Bidang Pendidikan dan Ilmu Geografi, 20(1), 24-29. https://doi.org/10.17977/ um017v20i12015p024

Tomlison, B., \& Avila. (2012). Seeing and saying for yourself: The roles of audio-visual mental aids for language teaching pedagogy. Cambridge Journal Lang Teach, 82-89.

Utami, W. S., Widodo, B. S., \& Daryono. (2019). Pengembangan bahan ajar Geografi SMA berbasis the total learning experience model. Jurnal Geografi; Geografi Dan Pengajarannya, 3(1), 204-215. https://doi.org/10.1017/CBO9780511712029

Winarti, Y., Indriyanti, D. R., \& Rahayu, E. S. (2016). Pengembangan bahan ajar ekologi kurikulum 2013 bermuatan sets melalui penerapan model problem based learning. Unnes Science Education Journal, 5(1), 14-23. https://doi.org/10.15294/ usej.v5i1.9564 